\title{
RELATIONSHIP BETWEEN BLOOD PRESSURE AND URINE PROTEINS IN TYPE 2 DIABETES MELITUS PATIENTS IN KEDUNGMUNDU HEALTH CENTER
}

\author{
Devi Etivia Purlinda ${ }^{a^{*}} ;$;idodo Widodo ${ }^{b}$ \\ ${ }^{a, b}$ Department of Health Analyst ; Poltekkes Kemenkes Semarang \\ 115 Wolter Monginsidi Street ; Semarang 50192 ; Indonesia
}

\begin{abstract}
Hyperglycemia trigger complication in type 2 Diabetes Mellitus patients such as diabetic nephropathy which cause of end-stage kidney failure. Monitoring of blood glucose and blood pressure are part of self-management to prevent complications of diabetes. This study aim to determine the characteristics of type 2 DM prolanis patients at the Kedungmundu Health Center based on age, sex, duration of suffering, blood pressure, and blood glucose. In addition, the relationship of blood pressure and urine protein is also analyzed in this study. This research use observational analytic design with cross-sectional approaching. The dependent and independent variables of this study are protein urine and blood pressure. Forty-six of DM patients are choosen as research's object using purposive sampling technique. The data was analyzed using chi-square. The results show that ratio between female and male type 2 diabetes patients are $71.7 \%$ to $28.3 \%$. In addition, about $63 \%$ of the patients are suffering type 2 diabetes less than 5 years. The results inform us that $50 \%$ of type 2 diabetes patients are $56-65$ years old, about $52.2 \%$ of them have hypertension, and $84.8 \%$ hyperglycemia. There is a significant relationship between blood pressure and urine protein with a p-value of 0.038 (p-value $\leqslant 0.05)$.
\end{abstract}

Keywords: urine protein; diabetes mellitus; blood pressure

\section{Introduction}

Kedungmundu Health Center is one of the First Level Health Service Units in the City of Semarang that implements the Prolanis Program. Prolanis is a health service system that involves participants, Health Facilities, and Health BPJS to maintain the quality of life of patients to be optimal (Raraswati, Heryaman, \& Soetedjo, 2018). Some prolanis patients at Kedungmundu Health Center in Semarang City suffer from chronic diseases, one of the Diabetes Mellitus (DM).

Diabetes occurs due to metabolic disorders characterized by increased blood glucose levels or hyperglycemia. Hyperglycemia occurs due to pancreatic beta-cell dysfunction so that insulin secretion is reduced. Insulin is a

\footnotetext{
*) Corresponding Author (Devi Etivia Purlinda)

E-mail: devietivia12@gmail.com
}

hormone that functions to regulate blood sugar levels to remain stable in the body(Fatimah, 2015) (Juhartini, 2017).

Prolonged hyperglycemia of DM patients due to self-management to poor and complications, one of which is diabetic nephropathy. Diabetes and hipertension were responsible for more than $50 \%$ of cases of end-stage renal disease (ESRD) (Nasri \& Rafieian-kopaei, 2015). The ability of each DM type 2 patient to manage and prevent complications is called Self-management. Self-management includes monitoring blood glucose levels, blood pressure, adopting healthy lifestyles, preventing obesity, and preventing prolonged emotional states (Sihombing, Sumber, \& Kesehatan, 2017).

The proportion of DM patients with high hypertension is $51.8 \%$ consisting of $45.8 \%$ men and $55.4 \%$ women of the total number of DM people that is 5253. Risk factors for 
hypertension in DM people include age $\geqslant 45$ years increased by 2.63 times, DM people who are obese increased by 1.57 times, and those with hypercholesterolemia increased by 1.68 times (Sihombing, Sumber, \& Kesehatan, 2017).

According to (Satria, Decroli, \& Afriwardi, 2018)(Rivandi et al., 2015) hypertension resulted in glomerular damage and increased Glomerular Filtration Rate (LFG). Increasing LFG can increase glomerular vascular permeability so that the protein escapes during filtration. The escape of protein is a sign of nephrosclerosis.

According to (Satria et a., 2018) (Rivandi et al., 2015) insulin resistance of type 2 DM patients can reduce pancreatic beta-cell insulin secretion and cause hyperglycemia. Hyperglycemia in a long period of time can increase LFG and kidney expansion in the direction of damage resulting in kidney failure. The presence of urine protein or urinary albumin whose levels $(>300 \mathrm{mg} /$ day or $>200$ $\mu \mathrm{g} / \mathrm{min}$ ) indicate chronic irreversible kidney failure. Based on the description, the researcher wants to know the characteristics of type $2 \mathrm{DM}$ patients based on age, sex, duration of illness, blood pressure, and blood glucose and whether there is a relationship between blood pressure and urine protein in type $2 \mathrm{DM}$ patients at the Kedungmundu Health Center.

\section{Method}

Observational (non-experimental) research, with a cross-sectional approach. The number of sample was calculated using an average estimation formula in accordance to $10 \%$ of the relative precision and a degree of confidence of $95 \%$, so we get a sample of 41 , but researchers use 46 respondents as research samples. The research sample was Prolanis DM type 2 patients at the Kedungmundu Health Center who examined the Kedungmundu Health Center in September 2019. The sample was a DM type 2 patient, based on the doctor's diagnosis in medical records suffering from type $2 \mathrm{DM}$, not yet having complications of kidney disease and malignancy.

Quantitative blood pressure measurement using a mercury sphygmomanometer (Accoson, Dekamet, United Kingdom) and a stethoscope. The measurement is done twice and the blood pressure data is the average value of the two measurements. Blood pressure data are categorized by (Directorate of P2PTM Ministry of Health, 2018) namely: Normal (less $<120 / 80$
mmHg), Prehypertension (120-139/80-89 $\mathrm{mmHg})$ Hypertension 1 (140-159/90-99 $\mathrm{mmHg}$ ), Hypertension 2 ( $\geqslant 160 / \geqslant 100 \mathrm{mmHg}$ ) The Measurement of urine protein is semi-quantitative because it is categorized, namely: (negative), (positive 1), (positive 2), (positive 3), and (positive 4). The reagent uses urine dipstick by dipping method. The principle of examination is the bromophenol indicator blue can detect albumin protein because it is very sensitive (Surya et al., 2018).

Specimens using morning urine, the middle portion of type 2 DM patients in Kedungmundu Public Health Center in Semarang City. and blood pressure was treated statistically with a computer program using the chi-square test because the data were in the form of categories, meaningful results were obtained $(\mathrm{p}<0.05)$.

\section{Result and Discussion}

Based on table 1 the highest number of respondents with type 2 diabetes mellitus in Kedungmundu Health Center 56-65 years old is 23 people (50\%) and at least $36-45$ years old is 3 people (6.5\%). According to (Sihombing, Sumber, \& Kesehatan, 2017) based on 2013 Riskesdas data that DM will increase at the age of $\geqslant 45$ years. The same results in the study of (Saputri, Nugraha, Pratama, \& Holidah, 2016) that the age range of the most type $2 \mathrm{DM}$ patients occurred at the age of 50-69 namely 160 people $(78.2 \%)$. Increased age or age of more than 40 years will occur in the body of generative processes one of which is a decrease in the work of beta-pancreatic cells, in secreting insulin resulting in glucose intolerance and hyperglycemia. Hyperglycemia occurs because the body is unable to respond to insulin or is resistant to insulin so that the body's peripheral cells cannot absorb glucose resulting in glucose in the blood vessels (Fatimah, 2015).

Table 1. Age Distribution of Respondents

\begin{tabular}{ccc}
\hline Age & Frequency (Person) & Percentage $(\%)$ \\
\hline 36 - 45 years & 3 & 6.5 \\
$46-55$ years & 7 & 15.2 \\
$56-65$ years & 23 & 50.0 \\
$66-85$ years & 13 & 28.3 \\
\hline Total & 46 & 100 \\
\hline
\end{tabular}

Based on table 2 the number of respondents DM patients type 2 at the Kedungmundu Health Center most women 
were 33 people $(71.7 \%)$ compared to men, 13 people $(28.3 \%)$. The highest number of DM patients is female, namely, 3287 people $(62.6 \%)$ compared to 1966 men (37.4\%)(Sihombing, Sumber, \& Kesehatan, 2017). According to (Saputri et al., 2016) DM sufferers are more dominant women than men because generally, women's activities are smaller than men so that glucose uptake is less, making it vulnerable to obesity and hyperglycemia. The results of (Azitha, Aprilia \& Ilhami, 2018) differ explained that physical activity is not related to blood glucose levels.

Table 2. Gender Distribution of Respondents

\begin{tabular}{ccc}
\hline Gender & $\begin{array}{c}\text { Frequency } \\
\text { (Person) }\end{array}$ & Percentage (\%) \\
\hline Female & 33 & 71.7 \\
Male & 13 & 28.3 \\
\hline Total & 46 & 100.0 \\
\hline
\end{tabular}

Table 3 Based on the number of respondents diabetic patients type 2 at the Kedungmundu Health Center the most is suffering from type $2 \mathrm{DM}$ for 0-5 years, namely 29 people $(63.0 \%)$ and the second-highest is 11 people $(23.9 \%)$ who suffer from type $2 \mathrm{DM}$ for 6-10 years. The number of respondents prolanis patients who suffer from type 2 diabetes for $11-20$ years is 8 people $(13 \%)$ of the total number of respondents.

According to (Lathifah, 2017) Diabetic nephropathy is one of the complications of DM due to changes in renal morphology and function, which occur after 2-5 years of diagnosis of DM. Diabetic nephropathy is characterized by albuminuria, because glomerular hypoperfusion and hyperfiltration favor the leakage of albumin from the glomerular. Damage to the kidney organs will reduce the function of the kidneys as an excretory organ which results in protein escaping during filtration and being urine. The presence of urine protein or microalbuminuria as a screening for chronic kidney disease (Miranda-díaz, Pazarín-villaseñor, Yanowsky-escatell, Andrade-sierra, \& Changes, 2016).
Table 3. Distribution of Illness Duration in Respondents

\begin{tabular}{ccc}
\hline $\begin{array}{c}\text { Duration of illness } \\
\text { (Year) }\end{array}$ & $\begin{array}{c}\text { Frequency } \\
\text { (Person) }\end{array}$ & Percentage (\%) \\
\hline $0-5$ & 29 & 63.0 \\
$6-10$ & 11 & 23.9 \\
$11-15$ & 2 & 4.3 \\
$16-20$ & 4 & 8.7 \\
\hline Total & 46 & 100.0 \\
\hline
\end{tabular}

Based on table 4 the number of respondents types $2 \mathrm{DM}$ patients at the Health Center Kedungmundu with hypertension as many as 24 people $(52.2 \%)$ consisting of hypertension 1 and hypertension 2 each as many as 12 people $(26.1 \%)$. Most respondents of type $2 \mathrm{DM}$ patients at the Kedungmundu Health Center are over 45 years old, 43 people $(93.5 \%)$, and those aged $35-45$ years are 3 people $(6.5 \%)$. The results of this study are in line with Riskesdas 2013 data that DM people with hypertension are $51.8 \%$ and those aged 45 years or more have the potential to experience hypertension 2.6 times, more than those aged less than 45 years (Sihombing et al., 2017b). According to (Rapina \& Saftarina, 2017) increasing age or getting older, the risk of hypertension is increasing. This is due to reduced arterial elasticity and stiffness in the artery walls due to elastic lamellar calcification.

Based on table 4 the normal distribution of blood pressure of respondents as many as 10 people $(21.7 \%)$, those with hypertension as many as 24 people $(52.2 \%)$, and those with prehypertension as many as 12 people $(26.1 \%)$. Respondents who have normal blood pressure $<130 / 80 \mathrm{mmHg}$, based on interviews due to several things including diligently monitoring blood pressure every month, regularly consult a doctor. Respondents also adopted a healthy lifestyle such as regular exercises such as walking, running, elderly exercise, reducing the consumption of foods with high salt content and fat. Regular exercise for 30-60 minute/ day, at least 3 days/week can prevent hypertension (Rapina \& Saftarina, 2017). Blood pressure monitoring is very important for patients with type $2 \mathrm{DM}$ to prevent complications including kidney failure (Saputri et al., 2016); (Rapina \& Saftarina, 2017). 
Table 4. Distribution of Blood Pressure in Respondents

\begin{tabular}{ccc}
\hline Blood Pressure & Frequency (Person) & Percentage $(\%)$ \\
\hline Normal & 10 & 21.7 \\
Prehypertension & 12 & 26.1 \\
Hypertension 1 & 12 & 26.1 \\
Hypertension 2 & 12 & 26.1 \\
Total & 46 & 100 \\
\hline
\end{tabular}

According to (Saputri et al., 2016) (Satria et al.,2018), monitoring fasting blood glucose (GDP) can prevent the progression of diabetic nephropathy. Based on table 5 the number of respondents DM patients type 2 at the Kedungmundu Health Center those whose fasting blood glucose was normal $(<126 \mathrm{mg} / \mathrm{dl})$ were 7 people $(15.2 \%)$ and those who increased $(\geqslant 126 \mathrm{mg} / \mathrm{dl})$ were 39 people $(84.8 \%)$. The results of the study are compared with the research of (Azitha et al., 2018) namely the normal GDP of more patients is 36 people $(30 \%)$ and the increase is less that is 84 people $(70 \%)$ of the total number of respondents. Chronic hyperglycemia in patients with type $2 \mathrm{DM}$ results in damage to small blood vessels (microvascular), glomerular lesions in the kidney triggering diabetic nephropathy, proteinuria and ending with end-stage renal disease or ESRD (Satria et al., 2018).

Table 5. Distribution of Blood Glucose In Respondents

\begin{tabular}{ccc}
\hline $\begin{array}{c}\text { Fasting Blood } \\
\text { Glucose }\end{array}$ & Frequency (Person) & Percentage (\%) \\
\hline Normal & 7 & 15.2 \\
Increased & 39 & 84.8 \\
Total & 46 & 100 \\
\hline
\end{tabular}

Based on the Cross-tabulation table, the highest urine protein $(+3)$ results were 8 people $(17.4 \%)$ when compared with urine protein that are $(+1)$ and $(+2)$, as many as 6 people $(13 \%)$. These results are under the research of (Surya, 2018) that the results of the examination of urine protein are the most $(+3)$ in patients with chronic kidney disease in RSUP Dr. M. Djamil Padang in 2015-2017. The results of previous studies stated that the results of the most positive urine protein tests in patients with type $2 \mathrm{DM}$ who are hypertensive and hypertensive are risk factors for diabetic nephropathy (Yulianti, 2014).
Table 6. Crosstabulation Blood Pressure and Urine protein

\begin{tabular}{cccccc}
\hline \multirow{2}{*}{$\begin{array}{c}\text { Blood } \\
\text { Pressure }\end{array}$} & negative & Urine protein & & \\
positive 1 & positive & positive & Total \\
Normal & 7 & 0 & 2 & 1 & 10 \\
& $70 . \%$ & $0 \%$ & $20 \%$ & $10 \%$ & $100 \%$ \\
Pre & 11 & 0 & 1 & 0 & 12 \\
hypertension & $91.7 \%$ & $0 \%$ & $8.3 \%$ & $0 \%$ & $100 \%$ \\
Hypertension & 5 & 2 & 1 & 4 & 12 \\
1 & $41.7 \%$ & $16.7 \%$ & $8.3 \%$ & $33.3 \%$ & $100 \%$ \\
Hypertension & 3 & 4 & 2 & 3 & 12 \\
2 & $25.0 \%$ & $33.3 \%$ & $16.7 \%$ & $25 \%$ & $100 \%$ \\
& 26 & 6 & 6 & 8 & 46 \\
Total & $56.5 \%$ & $13 . \%$ & $13 \%$ & $17.4 \%$ & $100 \%$ \\
\hline
\end{tabular}

Based on the Chi-Square table there is a relationship between blood pressure and urine protein with $\mathrm{p}=0.038 \quad(\mathrm{p}<0.05)$. According to (Surya et al., 2018) the presence of protein in urine indicates that there is glomerular and tubular kidney damage, one of the triggers is hypertension. This is because hypertension triggers glomerular capillary damage and causes kidney failure.

Table 7. Relationship between Blood Pressure and Urine protein

\begin{tabular}{cccc}
\hline Statistical Analysis & Value & df & $\begin{array}{c}\text { Asymp. Sig. } \\
\text { (2-sided) }\end{array}$ \\
\hline $\begin{array}{c}\text { Pearson } \\
\text { Chi-Square }\end{array}$ & $17754^{\mathrm{a}}$ & 9 & 0.038 \\
Likelihood ratio & 21348 & 9 & 0.011 \\
$\begin{array}{c}\text { Linear-by-Linear } \\
\text { Association }\end{array}$ & 4742 & 1 & 0.029 \\
N of Valid Cases & 46 & & \\
\hline
\end{tabular}

Urine protein is a strong predictor of chronic kidney disease. An increase in the amount of urine protein indicates decreased kidney function. Protein can escape in the urine due to increased permeability, damage to the glomerular barrier and decrease in tubular protein re-absorption.

\section{Conclusion and Suggestion}

High blood pressure is significantly increase the urine protein in type 2 diabetes patients at the Kedungmundu Public Health Center, Semarang City and vice versa. Furthermore, study about hypertension and hyperglycemic management in type $2 \mathrm{DM}$ 
patients are needed to minimize the incidence of ESRD. In addition, the type 2 diabetes patients have to monitor blood pressure urine protein and blood glucose regularly as well as implement a healthy lifestyle.

\section{Acknowledgments}

The authors thank to the Head of Semarang City Health Office, Head of the Semarang City Kedungmundu Health Center for their permission to conduct research and to BPSDMK for providing 2019 DIPA Risbinakes funds to the Poltekkes Kemenkes Semarang, so that this research can be carried out.

\section{References}

Azitha, M., Aprilia, D. and Ilhami, Y. R. (2018). Hubungan Aktivitas Fisik dengan Kadar Glukosa Darah Puasa pada Pasien Diabetes Melitus yang Datang ke Poli Klinik Penyakit Dalam Rumah Sakit M. Djamil Padang. Jurnal Kesehatan Andalas. 7(3), $\quad 400$ 404. https://doi.org/10.25077/jka.v7i3.89 3

Direktorat Pencegahan Dan Pengendalian Penyakit Tidak Menular. (2018) Klasifikasi Hipertensi http://www.p2ptm.kemkes.go.id/infogr aphic-p2ptm/hipertensi-penyakit-jantung -dan-pembuluh-darah/klasifikasi-hiperte nsi

Fatimah, R. N. (2015) Diabetes Mellitus Tipe 2.J. Majority. 4 (5), 93-101.

Juhartini, J. (2017). Hubungan antara Frekuensi Pemberian Konsultasi Gizi Dengan Kepatuhan Diet dan Kadar Gula Darah pada Diabetisi Tipe 2 di Unit Pelayanan Terpadu Diabetes Melitus Center Kota Ternate. Jurnal Riset Kesehatan, 6(2),35-40.

Lathifah.(2017).Hubungan Durasi Penyakit Dan Kadar Gula Darah Dengan Keluhan Subyektif Penderita Diabetes Melitus. Jurnal Berkala Epidemiologi,5 (2),231-239.https://doi.org/10.20473/jbe. v5i2.2017.231-239

Miranda-díaz, A. G., Pazarín-villaseñor, L., Yanowsky-escatell, F. G., Andrade-sierra, J., \& Changes, E. K. (2016). Oxidative Stress in Diabetic Nephropathy with Early Chronic Kidney Disease, 1-7 http://dx.doi.org/10.1155/2016/7047238
Nasri, H., \& Rafieian-kopaei, M. (2015). Diabetes Mellitus and Renal Failure : Prevention and Management, 20 (11), 1112-1120. https://doi.org/10.4103/1735-1995.17284 5

Rapina, R. and Saftarina, F. (2017). Penatalaksanaan Hipertensi Tingkat 2 dan Diabetes Mellitus Tipe II pada Wanita Usia 53 Tahun dengan Pendekatan Dokter Keluarga. J. Medula Unila. 7(2), 95-102.

Raraswati, A., Heryaman, H., \& Soetedjo, N. N. M. (2018). Peran Program Prolanis dalam Penurunan Kadar Gula Darah Puasa pada Pasien Diabetes Melitus Tipe 2 di Puskesmas Kecamatan Jatinangor Diabetic Patient in Puskesmas Kecamatan Jatinangor. JSK. 4 (2), 65-70.

Rivandi, J. et al. (2015). Hubungan Diabetes Mellitus Dengan Kejadian Gagal Ginjal Kronik Relationship Between Diabetic Nephropathy and Incident with Chronic Kidney Disease. Majority 4(9), 27-34

Saputri, S. W. et al. (2016). Study of Treatment of Type 2 Diabetes Mellitus with Hypertension in Outpatient Departement of dr. H. Koesnadi General Hospital Bondowoso in the Period of 2014', Pustaka Kesehatan, 4(3), 479-483.

Satria, H., Decroli, E. and Afriwardi. (2018). Faktor Risiko Pasien Nefropati Diabetik Yang Dirawat di Bagian Penyakit Dalam RSUP M. Djamil Padang. Jurnal Kesehatan Andalas, 7(2), 149-153.

Sihombing, M. (2017). Factors Associated with Hypertension Among Diabetes Mellitus People in Indonesia. (Basic Health Research 2013). Buletin Penelitian Kesehatan, $45(1), \quad 53 \quad-\quad 64$ http:/ / dx.doi.org/10.22435/bpk.v45i1.57 30.53-64

Surya. A.M, Pertiwi. D, Masrul. (2018). Hubungan Protein Urine dengan Laju Filtrasi Glomerulus pada Penderita Penyakit Ginjal Kronik Dewasa di RSUP. Dr. M. Djamil Padang tahun 2015-2017' Jurnal Kesehatan Andalas. 7(4), 469-474. https:// doi.org/10.25077/jka.v7i4.903.

Yulianti SR, Mukaddas A, Faustine I. (2014). Profil pengobatan pasien Diabetes Mellitus tipe 2 di Instalasi Rawat Inap RSUD Undata Palu tahun 2012. Jurnal of Natural Science, 3(1),40-46 